\title{
ARCHITECTURAL INNOVATIONS INFLUENCED BY CLIMATIC PHENOMENA (4.2 KA EVENT) IN THE LATE OLD KINGDOM (SAQQARA, EGYPT)
}

\author{
Kamil O. Kuraszkiewicz \\ Institute of Mediterranean and Oriental Cultures, Polish Academy of Sciences, Nowy Świat 72, \\ 00-330Warsaw,Poland, email: k.o.kuraszkiewicz@uw.edu.pl
}

\begin{abstract}
The work of the Polish-Egyptian Archaeological Mission at Saqqara revealed a cemetery of palace officials that was in use during the late Old Kingdom. The evidence found during the exploration of the tombs indicates that the tomb builders were aware of the problems resulting from torrential rains in last years of functioning of the cemetery and that architectural solutions have been invented against these problems. The discussed phenomena seem to be directly related to the 4.2 ka event.
\end{abstract}

Key words: Saqqara, architecture, 4.2 ka BP climate event, heavy rainfalls.

Manuscript received 7 July 2015, accepted 12 February 2016

\section{INTRODUCTION}

Quite obviously, architecture is influenced by needs, capabilities and potential of builders/users and any changes in these factors can produce modifications in architectural forms and solutions. This is true not only for domestic, but also for funerary architecture, even though the needs of its users may be seen as less sophisticated and less prone to changes than those of living ones.

A cemetery investigated by the Polish archaeological mission in Saqqara yields evidence of significant architectural modifications, being a response to changing climatic conditions. The cemetery in question, being part of the extensive Memphite necropolis, is situated in Saqqara, west of the Step Pyramid complex $\left(29^{\circ} 52^{\prime} 16.96\right.$ N, 31 $1^{\circ} 12^{\prime} 51.20$ E; cf. Fig. 1; for bibliography of the site, see: Myśliwiec et al., 2004: 31-36; Myśliwiec and Kuraszkiewicz, 2010: 23-24; Kuraszkiewicz, 2013: 6-7).

The area, extending between the funerary complex of Netjerykhet and the Dry Moat, is almost $10.00 \mathrm{~m}$ higher in the East than in the West and it comprises irregular terraces descending toward the West (cf. Fig. 2). The terraces were overlaid with deposits of dakka, formed as a result of stone processing, weathering and natural accumulation (Welc, 2011, Welc and Trzciński, 2013). Thus, viewed from the west, the area in question was a slope with bedrock terraces exposed in places, topped with the distinct horizontal band of the temenos wall with the towering silhouette of the Step Pyramid in the centre. Towards the end of the 5th Dynasty (24th century BC), a cemetery of palace officials has been estab- lished there, as a result of expansion of the Wenis cemetery. Contrary to the majority of Old Kingdom cemeteries, which were more or less incessantly used, often up to modern times, this cemetery witnessed extremely limited building activity after the end of the Old Kingdom (i.e. in the early 22nd century BC). Moreover, the area in question had not been examined archaeologically before the start of Polish excavations, meaning that the Old Kingdom layers and structures remained largely undisturbed despite undergoing natural degradation. All these circumstances allow the history of the site to be reconstructed. The cemetery functioned for approximately two centuries, including several stages of construction, alteration and destruction, as well as natural processes of disintegration, and has been abandoned before the Heracleopolitan period (i.e. before the mid-22nd century BC).

\section{DATING OF THE CEMETERY}

There are several factors that make dating of Old Kingdom non-royal tombs a difficult task (cf. e.g., Harpur, 1987; Strudwick, 1985: 2-52; Cherpion, 1989; Seidlmayer, 1997: 17-55; Swinton, 2014; Baud, 1998; Brovarski, 2005: 32-39; Brovarski, 2006; Jánosi, 2005: 36-74). Old Kingdom tomb inscriptions usually do not contain any dates, and royal names - if mentioned - do not always give a certain base for dating. Moreover, the chronology of the Old Kingdom in general is far from being established, due to the peculiarities of the dating system used, and also to the incompleteness of historical record (cf., e.g., von Beckerath, 1962; Strudwick, 1985: 2-3; Spalinger, 1994; Kanawati and Abder-Raziq, 


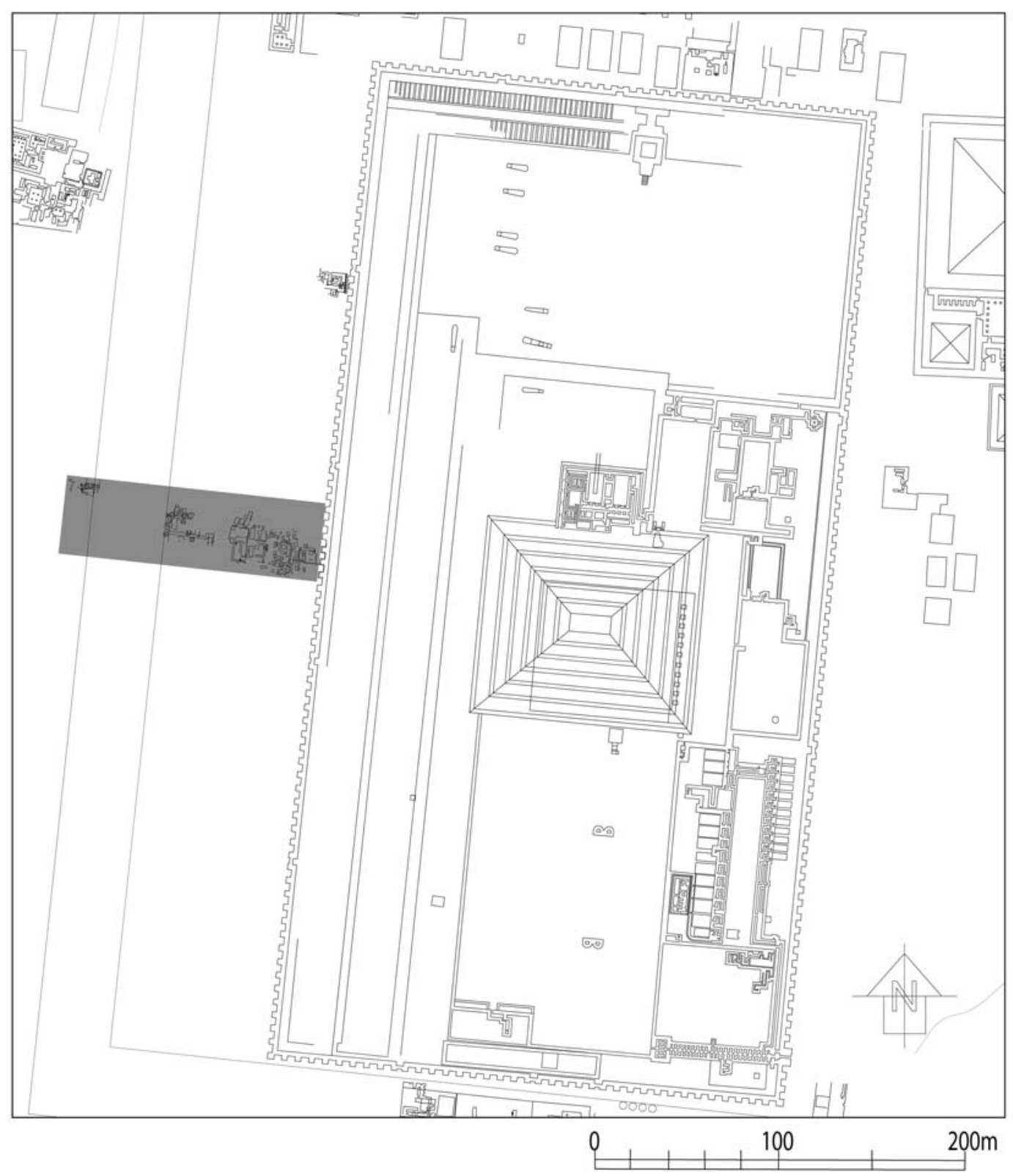

Fig. 1. Situation of the cemetery under discussion (drawing: K. Kuraszkiewicz).

2000: 21-23; Baud, 2006; Verner, 2008; the absolute dates are quoted here after Malek, 2000). Thus, absolute dates are generally avoided and it is only rarely that a more precise dating of a tomb than the attribution to particular reigns is possible (cf., e.g., Dee et al., 2008; Rowland, 2008; Bárta, 2013).

The relative chronology of the site is based on its layout and stratigraphy, as well as common features observed in the architecture of the tombs (Myśliwec et al., 2004: 246-250; Rzeuska, 2006: 381, 383; Myśliwiec and Kuraszkiewicz, 2010: 97; Mycielska-Dowgiałło and Woronko, 1998; Mycielska-Dowgiałło et al., 1999; Szafrański, 1999; Ćwiek, 2000; Kuraszkiewicz, 2007; Welc, 2011; Myśliwiec, 2011; Kuraszkiewicz, 2013: 22-23, 274-284). This, combined with the three fixed points described below, allow approximate dates to be proposed for the majority of the tombs. The chronological frame of the cemetery under discussion is based on three points, that is tombs belonging to Merefnebef,
Ny-Pepy and Ikhi/Meri, which can be dated with a reasonable precision, as discussed below.

The construction of the tomb of Merefnebef started late in the reign of Teti (c. 2345-2323 BC), was continued through the short reign of Weserkare (c. 2323-2321 BC), and abandoned early in the reign of Pepy I (c. 2321-2287 BC) (Myśliwiec, 2011; Myśliwiec et al., 2004: 246-250). The latest dated tomb is that of Ny-Pepy. was built in the late part of the reign of Pepy II (c. 2278-2184 BC) (Myśliwiec, 2008: 174; Kuraszkiewicz, 2013: 100-107); postdating it there was at least one phase of the cemetery's development.

The tomb of Ikhi/Meri hewn in the western bank of the Dry Moat dates from the final years of Pepy I to Merenre (c. 2287-2278 BC) (Kuraszkiewicz, 2014; cf. Myśliwiec, 2003: 121-126; Kuraszkiewicz, 2003: 137-140; Rzeuska, 2003b: 144-150; Kuraszkiewicz, 2006: 193-195). The main owner of this tomb, god's sealer Ikhi/Meri, together with his 


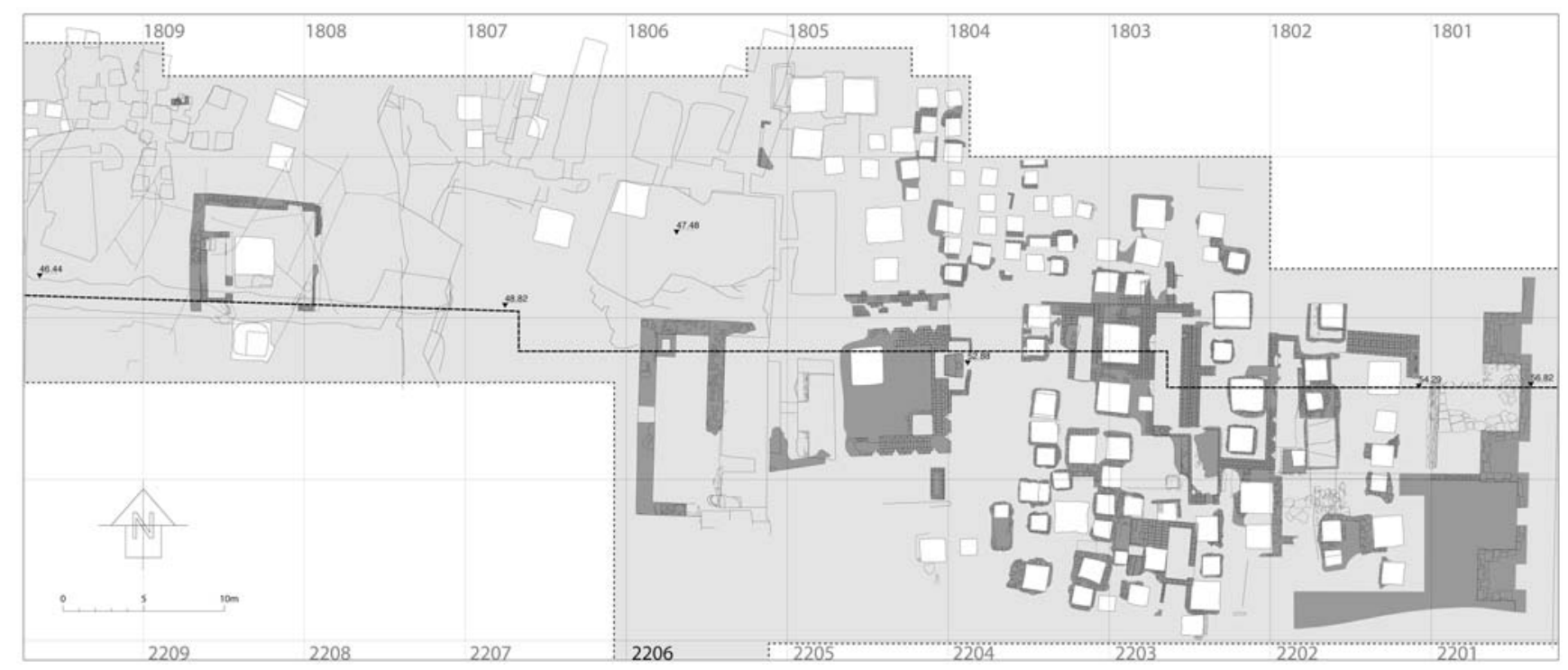

Fig. 2. East-West cross-section through the cemetery (drawing: B. Błaszczuk/K. Kuraszkiewicz).



Fig. 3. Plan of the cemetery (drawing: M. Niepokólczycki/K. Kuraszkiewicz).

son (and namesake), participated in the royal expedition to Wadi Hammamat, which is well dated to the year after the 18th census of Pepy I (cf. Kuraszkiewicz, 2014 for bibliography). Because the titles attested for the younger Ikhi are higher in the tomb than in the Wadi Hammamat graffiti, the tomb in Saqqara must have been decorated after that date (although precise correlation of the regnal years of Pepy I with absolute dates does not seem to be possible, due to the problems discussed, e.g., by Verner, 2008).

\section{THE CEMETERY}

As noted above, the cemetery has been established on a ground sloping toward the West which favoured a linear arrangement of mastabas in longitudinal rows, approached from the South, through the wadi of Wenis (Figs 2, 3). The access to particular tombs was possible by means of longitudinal alleys or paths between the rows of mastabas. East-west passages between the rows were present at initial stages of the cemetery's development, but most of them were subsequently overbuilt (Kuraszkiewicz, 2013: 278-283).

\section{ARCHITECTURE OF THE TOMBS}

The cemetery comprised mainly mastabas, but also a few rock-cut tombs. The mastabas were built of sun-dried bricks, made of Nile silt or local marly limestone - tafl, occasionally with addition of stone (tafl or higher quality limestone, usually in the form of irregular chips or - rather rarely - dressed blocks), with silt or tafl mixture used both as mortar and plaster. This type of material is relatively resilient, but prone to weathering and dissolving in water (Kuraszkiewicz, 2013: 242-243; cf. Kemp, 2000; Spencer, 1979; Spencer, 1994).

An Egyptian tomb consisted of two essential elements: a cult place and a burial place (Fig. 4). The cult place had to be accessible for the living and thus situated at the ground level, and its form depended on the owner's wealth: both a decorated chapel with elaborate false door and offering table, and a simple arrangement of a niche with a place marked for offerings served basically the same function. A burial place was intended to preserve the body buried inside and to guarantee its safety, and therefore it should be placed as deep as possible, in order to prevent - or hinder at least - any unauthorised entry. Almost all burial places in the cemetery un- 


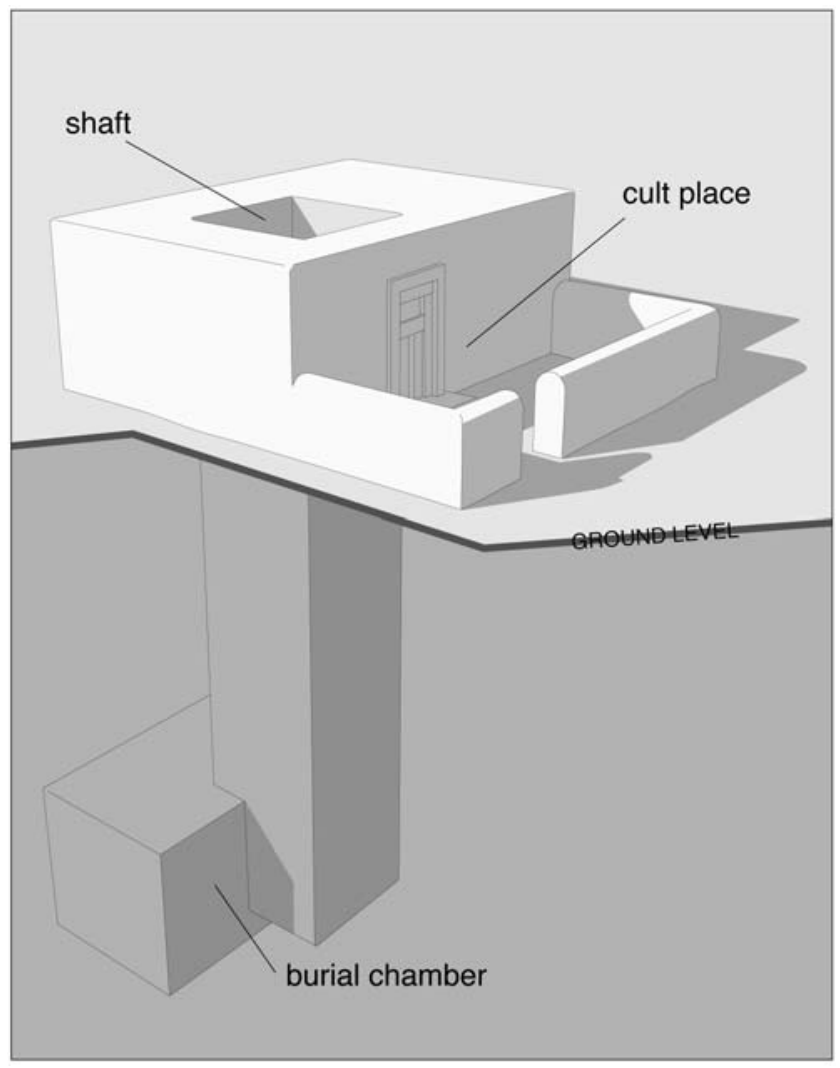

Fig. 4. Structure of an Old Kingdom mastaba (drawing: K. Kuraszkiewicz). der discussion have the form of a rock-cut chamber accessible through a vertical shaft (cf., e.g., Reisner, 1936: 57-74; Dodson and Ikram, 2008: 13-22, 136; Bolshakov, 1997: 24-25, 28-30, 121-122). After the funeral, the access to the burial chamber was blocked, usually by filling the shaft with by-products of the tomb construction, i.e. tafl and limestone chips, broken bricks, gravel etc. (cf. Kuraszkiewicz 2013: 267-269, with references).

\section{EVIDENCE OF THE CLIMATIC CHANGES AT THE END OF THE OLD KINGDOM}

Towards the end of the Old Kingdom (from the second half of the reign of Pepy II), torrential rains had become significantly more frequent and violent (Trzciński et al., 2010; Welc and Trzciński, 2013; Welc and Marks, 2014). Huge streams of water mixed with mud and debris were flowing down the slope destroying or damaging mastabas' superstructures, transporting their remains westward and getting into underground rooms (Fig. 5). There is evidence of walls having been repeatedly destroyed by water and then rebuilt, in some cases with revetments added. The floods deposited also a layer of debris on chapel's floors and offering places. Water stagnating in many of the burial chambers led to the damage and probably desecration of human remains (the preservation of which being prerequisite for the afterlife, according to Egyptian beliefs) and funerary equipment (Fig. 6; Myśliwiec, 2004: 121; cf. Kowalska and Kuraszkiewicz, 2011: 95-97; Kuraszkiewicz, 2011: 532-533). The dating of the tombs, as discussed above, suggests that the rainy period evidenced at the West Saqqara cemetery is to be identified with the 4.2 ka event (cf. Walker et al. 2012: 653-656).

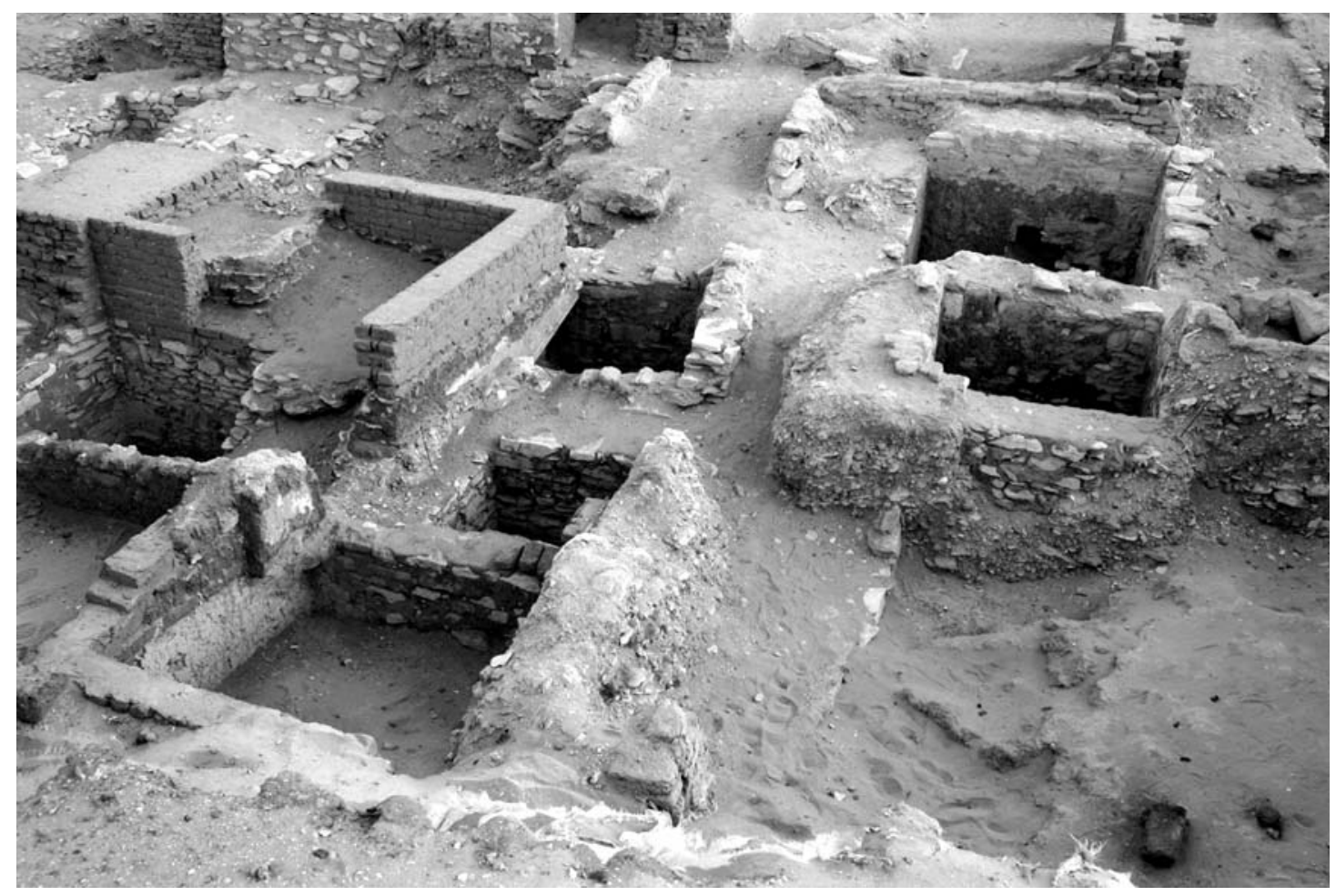

Fig. 5. Destroyed superstructures of Old Kingdom mastabas (photo: J. Dąbrowski). 


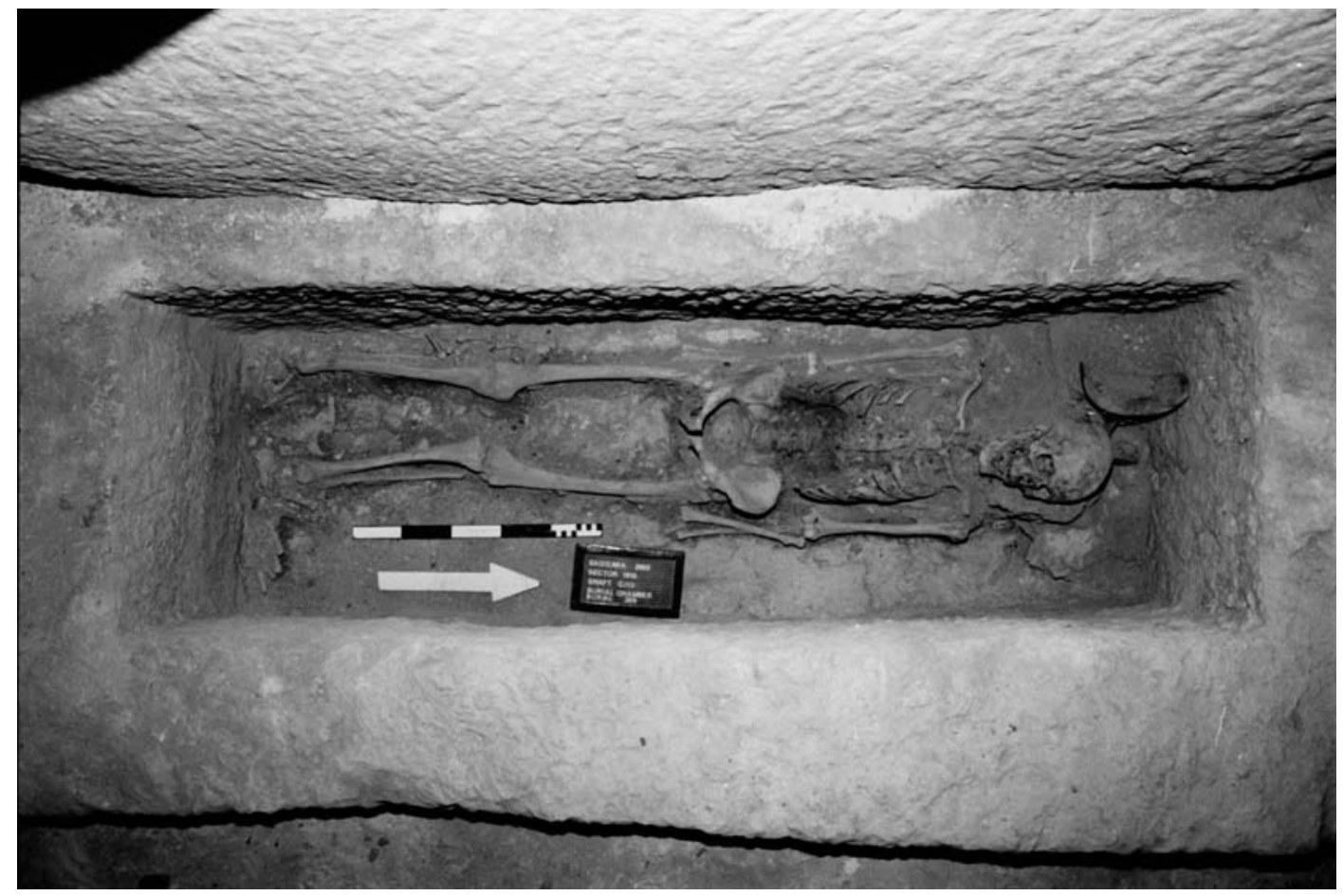

Fig. 6. An Old Kingdom burial (no. 389) covered with mud deposited by water, before and after clearing (photo: M. Jawornicki).

\section{THE SOLUTION AGAINST WATER DESTRUCTION: ABOVE GROUND}

In numerous offering places in the cemetery under discussion an interesting phenomenon can be observed: the false doors and offering tables covered with fine reliefs and polychromy have been subsequently painted white (Fig. 7; cf. Kuraszkiewicz, 2013: 205-206). In some cases the white coating (consisting of numerous layers of paint) was so thick that it obscured the name and image of the deceased and offering formula, being of crucial importance for the posthumous cult. This means that at some point the practice of painting cult places white was even more important than their original design. The appearance of this practice can be dated to the second part of the reign of Pepy II (phase Ff of the cemetery development, cf. Kuraszkiewicz, 2013: 274-275). White being the colour of purity in Egyptian beliefs (cf., e.g. Kees, 1943), it may be supposed that the practice was aimed at restoring the ritual purity to offering places desecrated as a result of the above-mentioned frequent flooding of the cemetery, and the multiple layers of white paint evidently correspond to repeated rainfalls. Thus, after heavy rains that caused damage to the tombs, the superstructures had to be repaired and ritually purified, and the evidence of such activity may be seen as a dating criterion (Kuraszkiewicz, 2002: 366-368; Kowalska and Kuraszkiewicz, 2011; cf. Rzeuska, 2003a).

\section{THE PROTECTIVE SOLUTION: UNDERGROUND}

In a number of tombs dated securely to the 5th and early 6th Dynasty the floor of the burial chamber was situated lower than the bottom of the shaft or on the level with it. Such

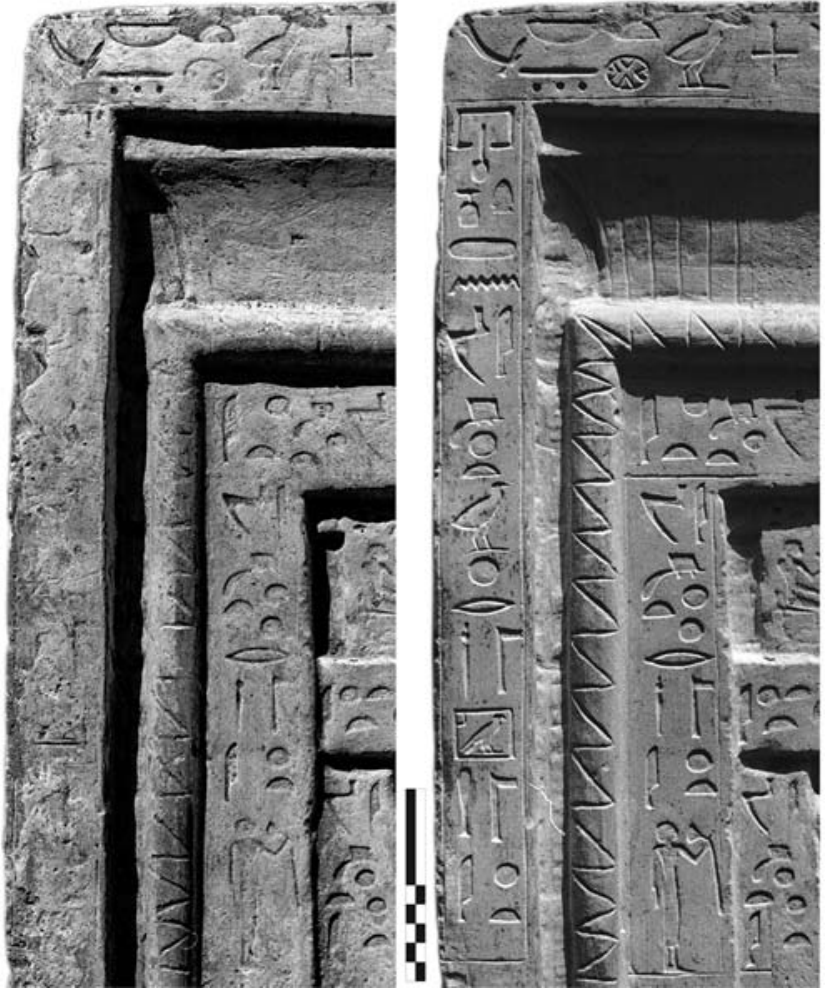

Fig. 7. Fragment of the false door of Kheti with remains of the layer of whitewash and after clearing (photo: M. Jawornicki).

arrangement seems to reflect the desire to protect the dead body from being damaged by robbers. However, towards the end of the dynasty in a number of tomb superstructures "raised" burial chamber are found, i.e. hewn above the shaft's bottom (the difference of levels reaching one meter). 

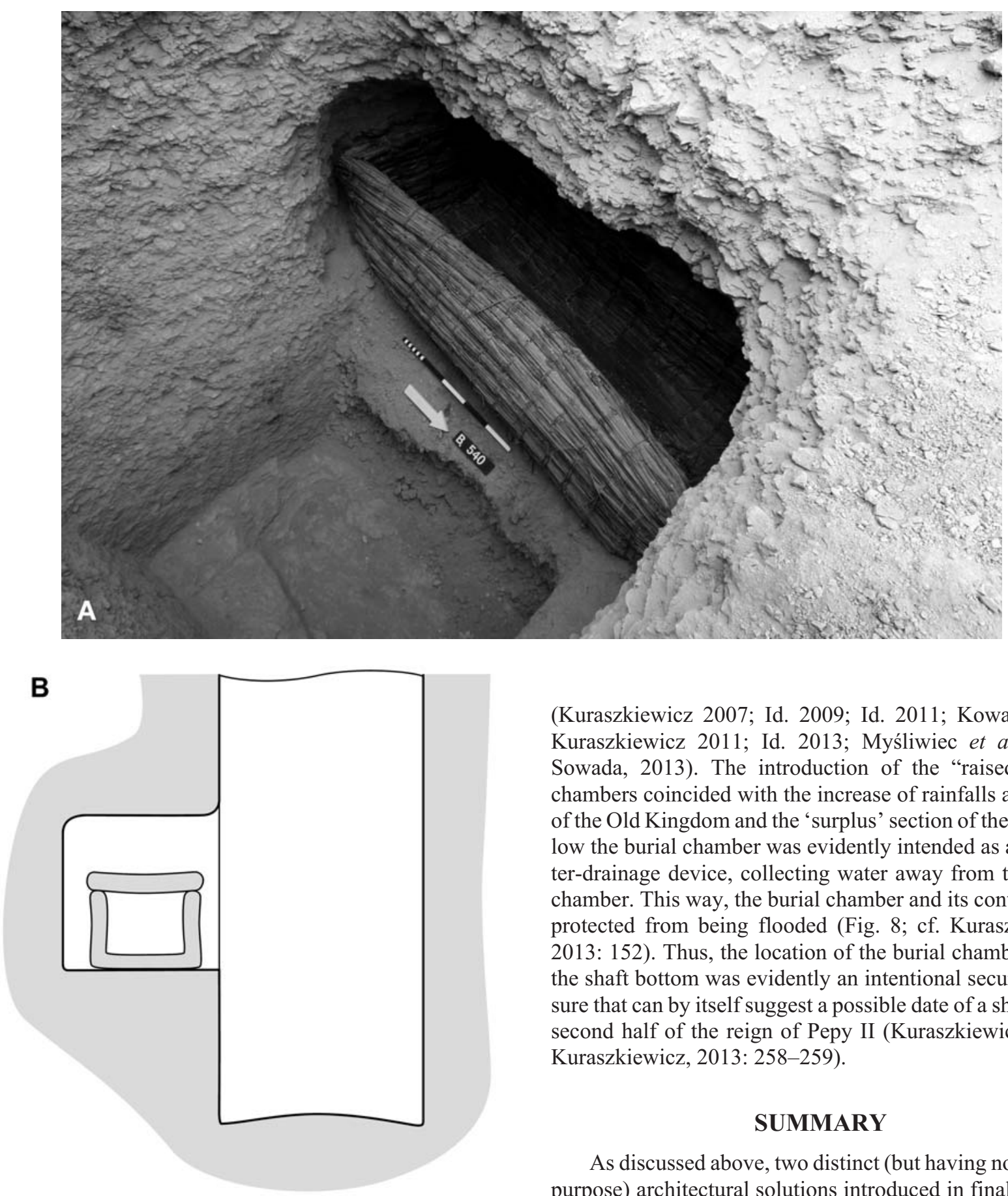

(Kuraszkiewicz 2007; Id. 2009; Id. 2011; Kowalska and Kuraszkiewicz 2011; Id. 2013; Myśliwiec et al., 2012; Sowada, 2013). The introduction of the "raised" burial chambers coincided with the increase of rainfalls at the end of the Old Kingdom and the 'surplus' section of the shaft below the burial chamber was evidently intended as a rainwater-drainage device, collecting water away from the burial chamber. This way, the burial chamber and its contents was protected from being flooded (Fig. 8; cf. Kuraszkiewicz, 2013: 152). Thus, the location of the burial chamber above the shaft bottom was evidently an intentional security measure that can by itself suggest a possible date of a shaft in the second half of the reign of Pepy II (Kuraszkiewicz, 2009; Kuraszkiewicz, 2013: 258-259).

\section{SUMMARY}

As discussed above, two distinct (but having no obvious purpose) architectural solutions introduced in final years of the Old Kingdom (early 22nd century BC) seem to be the tomb builders' response to the intensive rainfalls, being one

Fig. 8. Shaft with raised burial chamber: $\mathbf{A}$ - view of the burial chamber of Shaft 81 (photo: J. Dąbrowski); B - schematic crosssection of a model shaft (drawing: K. Kuraszkiewicz).

It should be emphasised that, although burial shafts were blocked after the funeral (as mentioned above), the blockage was intended as a security measure against robbery, and thus there was no need of the shaft's fill to be watertight. During the floods, water penetrated into burial chambers and stagnated therein, causing decomposition of the funerary equipment and of burials themselves and leaving deposits of mud; there is an ample evidence of such occurrences in Saqqara of the aspects of the climatic changes that marked the Middle-Late Holocene Boundary (4.2 ka event, cf., e.g., Walker et al., 2012; Welc and Trzciński, 2013; Welc and Marks, 2014). The evidence of similar processes is found also in other parts of the Saqqara necropolis (cf. Sowada, 2013), it remains, however, largely unpublished (cf. Kuraszkiewicz 2013: 224-225, 246-247). Importantly, the architectural analysis provides not only a corroboration of paleoclimatic data obtained from other sources, but also a dating criterion that may be applied to other funerary structures.

The paper has been prepared with the financial support of the National Science Centre, Grant No. UMO-2013/11/B/ HS3/04472. 


\section{REFERENCES}

Bárta, M., 2013. Radiocarbon dates for the Old Kingdom and their Correspondences. In: J.A. Shortland, C.B. Ramsey (eds.), Radiocarbon and the Chronologies of Ancient Egypt Oxbow Books, Oxford and Oakville, 218-223.

Baud, M., 1998. À propos des critères iconographiques établis par Nadine Cherpion. In: N. Grimal (ed.), Les critères de datation stylistiques à l'Ancien Empire (Bibliothèque d'Étude 120). IFAO, Le Caire, 31-95.

Baud, M., 2006. The Relative Chronology of Dynasties 6 and 8. In: E. Hornung, R. Krauss, D.A. Warburton (eds.), Ancient Egyptian Chronology. Brill, Leiden-Boston, 144-158.

Bolshakov, A.O., 1997. Man and his Double in Egyptian Ideology of the Old Kingdom, (=Ägypten und Altes Testament 37). Harrasowitz, Wiesbaden.

Brovarski, E., 2005. The late Old Kingdom at South Saqqara. In: L. Pantalacci, Ch. Berger-el-Naggar (eds.) Des Néferkarê aux Montouhotep. Travaux archéologiques sur la fin de la Vie dynastie et la Première Période Intermédiaire. Maison de l'Orient et de la Méditerranée, Lyon, 31-71.

Brovarski, E., 2006. False doors \& history: the Sixth Dynasty. In: M. Bárta (ed.), The Old Kingdom Art and Archaeology. Proceedings of the Conference Held in Prague, May 31-June 4, 2004. Czech Institute of Egyptology, Prague, 71-118.

Cherpion, N., 1989. Mastabas et hypogées d'Ancien Empire. Le problème de la datation. Connaissance de l'Egypte Ancienne, Bruxelles.

Ćwiek, A. 2000., The Stratigraphy of West Saqqara. Preliminary Remarks. Polish Archaeology in the Mediterranean 11, 109117.

Dee, M., Ramsay, C.B., Rowland, J.M., 2008. Evaluating the effectiveness of radiocarbon studies of the Old Kingdom. In: H. Vymazalová, M. Bárta (eds.), Chronology and Archaeology in Ancient Egypt (the Third Millennium B.C.), Czech Institute of Egyptology, Prague, 1-9.

Dodson, A., Ikram, S. 2008., The Tomb in Ancient Egypt: Royal and Private Sepulchres From the Early Dynastic Period to the Romans, Thames \& Hudson, London.

Harpur, Y., 1987. Decoration in Egyptian Tombs of the Old Kingdom. KPI, London, New York.

Jánosi, P., 2005. Giza in der 4. Dynastie. Die Baugeschichte und Belegung einer Nekropole des Alten Reiches. Verlag der Österreichischen Akademie der Wissenschaften, Wien.

Kanawati, N., Abder-Raziq, M., 2000. The Teti Cemetery at Saqqara VI: The Tomb of Nikauisesi (=ACE Reports 14). Aris and Phillips, Warminster.

Kees, H. 1943. Farbensymbolik in ägyptischen religiösen Texten (Nachrichten der Akademie der Wissenschaften in Göttingen 11), Göttingen.

Kemp, B., 2000. Soil (including mud-brick architecture). In: P.T. Nicholson, I. Shaw (eds.), Ancient Egyptian Materials and Technology, Cambridge University Press, Cambridge, 78103.

Kowalska, A., Kuraszkiewicz, K.O., 2011. Some Aspects of Purification after Death in Old Kingdom Egypt. In: J. PopielskaGrzybowska, J. Iwaszczuk (eds.), Studies on Religion: Seeking Origins and Manifestations of Religion (Acta Archaeologica Pultuskiensia III). Department of Archaeology and Anthropology, Pultusk, 95-97

Kowalska, A., Kuraszkiewicz, K.O., 2013. The end of a world caused by water. The case of Old Kingdom Egypt In: j. Popielska-Grzybowska, J. Iwaszczuk (eds.), Studies on Disasters, Catastrophes and the Ends of the World in Sources (Acta Archaeologica Pultuskiensia IV), Department of Archaeology and Anthropology, Pułtusk, 173-176.
Kuraszkiewicz, K.O., 2002. Inscribed Objects from the Old Kingdom Necropolis West of the Step Pyramid (with remarks on their coating). Archiv Orientalni 70, 351-176.

Kuraszkiewicz, K.O., 2003. Saqqara 2002: Inscriptions, Polish Archaeology in the Mediterranean 14, 133-140.

Kuraszkiewicz, K.O., 2006. The title xtmtj-nTr - god's sealer - in the Old Kingdom. In: M. Bárta (ed.), The Old Kingdom Art and Archaeology. Proceedings of the Conference Held in Prague, May 31-June 4, 2004. Czech Institute of Egyptology, Prague, 193-202.

Kuraszkiewicz, K.O., 2007. Remarks on the development of the Old Kingdom necropolis, Polish Archaeology in the Mediterranean $17,169-175$.

Kuraszkiewicz, K.O., 2009. More remarks on late Old Kingdom mastabas west of the Step Pyramid, Polish Archaeology in the Mediterranean 18, 165-173.

Kuraszkiewicz, K.O., 2011. The practical behind the ritual. Observations on the Sixth Dynasty funerary architecture. In: M. Bárta, F. Coppens, J. Krejči (eds.) Abusir and Saqqara in the Year 2010. Czech Institute of Egyptology, Prague, 530-536.

Kuraszkiewicz, K.O., 2013. Saqqara V. Old Kingdom Structures between the Step Pyramid Complex and the Dry Moat. Part 1: Architecture and Development of the Necropolis. Neriton, Varsovie.

Kuraszkiewicz, K.O., 2014. The Tomb of Ikhi/Mery in Saqqara and Royal Expeditions During the 6th Dynasty. Études et Travaux 27, 201-216.

Malek, J., 2000. The Old Kingdom (c. 2686-2160 BC). In: I. Shaw (ed.), The Oxford History of Ancient Egypt, Oxford University Press, Oxford, 2000, 83-107.

Mycielska-Dowgiałło E., Woronko, B., 1998. Genetic-climatic interpretation of mineral deposits uncovered in Section $\mathrm{N}$ and sections perpendicular to it, Polish Archaeology in the Mediterranean 10, 107-112.

Mycielska-Dowgiałło, E., Szafran ski, Z.E., Woronko, B., 1999. Reconstruction of morpho-dynamic processes during the last 4700 years period in archaeological site (Area I) at Saqqara (Egypt), Geoarqueologia i Quaternari Litoral. Memorial M.P. Fumanal, Valencia, 167-178.

Myśliwiec, K., 2003. West Saqqara in 2002. Polish Archaeology in the Mediterranean 14, 121-126.

Myśliwiec, K., 2004. West Saqqara. Archaeological Activities, 2003. Polish Archaeology in the Mediterranean 15, 111-122.

Mys liwiec, K., 2008. A Contribution to the Second Style in Old Kingdom Art. In: S.H. D'Auria (ed.), Servant of Mut. Studies in Honor of Richard A. Fazzini, Brill, Leiden-Boston, 170 178.

Myśliwiec, K., 2011. Dating the Tombs of Merefnebef and Nyankhnefertem. In: M. Bárta, F. Coppens, J. Krejči (Eds.) Abusir and Saqqara in the Year 2010. Czech Institute of Egyptology, Prague, 651-663.

Myśliwiec, K., Kuraszkiewicz, K., Czerwik, D., Rzeuska, T., Kaczmarek, M., Kowalska, A., Radomska, M., Godziejewski, Z., 2004. Saqqara I. The Tomb of Merefnebef. Neriton, Varsovie.

Myśliwiec, K., Kuraszkiewicz, K. (with contributions by Kowalska, A., Radomska, M., Rzeuska, T., Kaczmarek, M., Kozieradzka, I., Godziejewski, Z., Ikram, S., Zatorska A.), 2010. Saqqara IV. The Funerary Complex of Nyankhnefertem. Neriton, Varsovie.

Myśliwiec, K., Welc, F., Trzciński, J., 2012. Geoarchaeological and palaeoclimatic research by the Polish Archaeological Mission in Saqqara. An updated overview, Études et Travaux 25, 275-296.

Reisner, G.A., 1936. The Development of the Egyptian Tomb Down to the Accession of Cheops, Harvard University Press, Cambridge. 
Rowland, J.M., 2008. Building bridges between radiocarbon, relative and historical chronologies: the case of early Egypt. In: H. Vymazalová, M. Bárta (eds.), Chronology and Archaeology in Ancient Egypt (the Third Millennium B.C.), Czech Institute of Egyptology, Prague, 10-22.

Rzeuska, T.I., 2003a. Some remarks on the white painted funerary cult pottery from West Saqqara. In: J. Popielska-Grzybowska (ed.), Egypt 2001: Perspectives of Research. Second Central European Conference of Young Egyptologists, Warsaw, 125134.

Rzeuska, T.I., 2003b. West Saqqara. The Pottery, 2002. Polish Archaeology in the Mediterranean 14, 144-150.

Rzeuska T.I. 2006., Saqqara II. Pottery of the Late Old Kingdom. Funerary Pottery and Burial Customs. Neriton, Varsovie.

Seidlmayer, S.J., 1997. Stil und Statistik. Die Datierung dekorierter Gräber des Alten Reiches - ein Problem der Methode. In: C. Dobiat, K. Leidorf (eds.), Archäologie und Korrespondenz-a nalyse: Beispiele, Fragen, Perspektiven. Espelkamp, 17-51.

Sowada, K., 2013. Evidence for late Third Millennium weather events from a Sixth Dynasty tomb at Saqqara. Studia Quaternaria 30/2, 69-74.

Spalinger, A., 1994. Dated Texts of the Old Kingdom. Studien zur altägyptischen Kultur 21, 275-319.

Spencer, A.J., 1979. Brick Architecture in Ancient Egypt, Aris \& Phillips, Warminster.

Spencer, A.J., 1994. Mud brick: its decay and detection in Upper and Lower Egypt. In: Ch. Eyre, A. Leahy, L. Montagno Leahy (eds.) The Unbroken Reed. Studies in the Culture and Heritage of Ancient Egypt in Honour of A.F. Shore. Egypt Exploration Society, London, 315-320.

Strudwick, N., 1985. The Administration of Egypt in the Old Kingdom: The Highest Titles and Their Holders, London.
Swinton, J., 2014. Dating the Tombs of the Egyptian Old Kingdom (Archaeopress Egyptology 2). Oxford.

Szafrański, Z., 1999. Observations on stratigraphy, Polish Archaeology in the Mediterranean 10, 91-96.

Trzciński, J., Kuraszkiewicz, K.O., Welc, F., 2010. Preliminary report on geoarchaeological research in West Saqqara, Polish Archaeology in the Mediterranean 19, 194-208.

Verner, M., 2008. The system of dating in the Old Kingdom. In: H. Vymazalová, M. Bárta (eds.), Chronology and Archaeology in Ancient Egypt (the Third Millennium B.C.), Czech Institute of Egyptology, Prague, 23-43.

von Beckerath, J., 1962. The Date of the End of the Old Kingdom. Journal of Near Eastern Studies 21, 140-147.

Walker, M.J.C., Berkelhammer, M., Björck, S., Cwynar, L.C., Fisher, D.A., Long, A.J., Lowe, J.J., Newnham, R.M., Rasmussen, S.O., Weiss, H., 2012. Formal subdivision of the Holocene Series/Epoch: a Discussion Paper by a Working Group of INTIMATE (Integration of ice-core, marine and terrestrial records) and the Subcommission on Quaternary Stratigraphy (International Commission on Stratigraphy). Journal of Quaternary Science 27, 649-659.

Welc, F., 2011. The Third Dynasty Open Quarry West of the Netjerykhet Pyramid Complex (Saqqara), Études et Travaux 24, 272-304.

Welc, F., Marks, L., 2014. Climate change at the end of the Old Kingdom in Egypt around 4200 BP: New geoarchaeological evidence, Quaternary International 324, 124-133

Welc, F., Trzcin ski, J., 2013. Geology of the site. In: K. Myśliwiec (ed.) Saqqara V. Old Kingdom Structures between the Step Pyramid Complex and the Dry Moat. Part 2: Geology - Anthropology - Finds - Conservation. Neriton, Varsovie, 323343. 